\title{
PEACE EDUCATION BASED ON LOCAL WISDOM OF PELA GANDONG IN SOCIAL SCIENCE
}

\author{
Anju Nofarof Hasudungan ${ }^{1}$ \\ ${ }^{1}$ History teacher at SMAN 1 Rupat, Riau Province
}

\begin{tabular}{l}
\multicolumn{1}{c}{ Corresponding Author: Anju No } \\
\hline ARTICLE INFO \\
\hline Received: $02-07-2020$ \\
Accepted: 04-10-2020 \\
Published: October 2020 \\
Volume: 3 \\
Issue: 2 \\
DOI: \\
https://doi.org/10.33019/berumpun.v3i \\
$\underline{\text { KEY }}$ \\
\hline
\end{tabular}

Social Science, Peace Education, Local Wisdom, Pela Gandong

\section{ABSTRACT}

Post-conflict recovery efforts in Ambon-Maluku, which was the biggest civil conflict after the collapse of President Soeharto's government (New Order), are not only needed by the generation who experienced conflict. But recovery is also needed by the generation that does not experience this conflict, namely students today. Like students in SMPN 9 Ambon City and SMPN 4 Salahutu Liang Central Maluku who are the next generation of Maluku and of course who will maintain Ambon peace in the future. The purpose of this study is to describe how Social Science integrated the value of peace education based on local wisdom pela gandong. This research was conducted in January 2018 and continued in November 2019. The research method uses descriptive qualitative case study approach. Data collection was carried out by means of literature study, interviews, participatory observation, and document analysis. The results showed, with the existence of social conflict material in Social Science which was then integrated with Ambon conflict material and peace education based on Pela Gandong. Thus, students have improved both in terms of knowledge, skills and attitudes in understanding conflict and peace education through Social Science. At the same time cut off the trauma, mutual suspicion and hatred experienced by students so far.

\section{INTRODUCTION}

Ambon conflict is the biggest civil conflict after the New Order collapsed on May 21, 1998. This conflict is two religious groups namely, Islam and Christianity. In the opinion Adam (2013) violence in the capital of Maluku is not only the most bitter, but also the first brutal conflict in post-New Order Indonesia. Adam classified the Maluku conflict as "high intensity and protracted", due to the large number of direct killings. Based on the report (International Crisis Group, 2000) mention of all conflicts that occurred in Indonesia after 1998. Religious violence in Ambon, which is one of the largest urban centers in eastern Indonesia and the provincial capital of Maluku, is the most terrible in terms of the scale of death and 
destruction. The Ambon turmoil resulted in thousands of deaths and tens of thousands of injuries. It is estimated that one third to half of the population is displaced, and countless traits are leveled (Qurtuby, 2013). In fact, the Ambon conflict presents a war that is often described as a crusade mission, Christian against Muslims (Turner, 2006). Today, the Ambon conflict has been resolved and conflict resolution can be reached on February 12, 2002. Pela Gandong's local wisdom has a role as conflict resolution (Habib Shulton Asnawi dan Eka Prasetiawati, 2018) (Hartanti, Nur Lailiya, Fathul Karimul Khair, 2018). The Maluku people interpret Pela as a system of fellowship, a friendship model or a system of fraternity that is developed between all indigenous people of two or more countries. The bond system has been established by the ancestors in special circumstances with certain rights and obligations agreed upon. According to Colley (Wenno \& Akihary, 2010) that Pela as a bond or relationship between all residents of two or more villages based on adat.

After the Ambon conflict, the next work is an effort to build peace so that peace can be maintained and prevent past conflicts from happening again. Peace education is most effective when peace and conflict skills are exercised in the school environment (Baldo \& Furniss, 1998). School institutions can be a place to equip and facilitate students as the next generation to have the skills, knowledge and attitudes of peace-loving. Method of getting students closer to Social Science material. Namely, contextualizing local sources where the student lives. These sources are not only conveyed to the extent of knowledge, but must be able to improve skills and instill affective students themselves. Local resources taught in Social Science can be in the form of local wisdom Pela Gandong. That, conflict does not only affect the group but also on individuals (students). Therefore, it is necessary to transmit Pela Gandong culture to students to maintain peace. Through learning, especially Social Science which have the aim of forming learners learn how to live in harmony in a society where many different groups live side by side. Students learn topics such as socialization, conflict, collaboration, heroes, heroines, ethical diversity, human rights and problems that arise in society.

Kementerian Pendidikan dan Kebudayaan Republik Indonesia (2013) clearly states that the objectives of learning can be achieved optimally with the approach of local wisdom, culture, and customs that are born, grow and develop and are preserved (regenerated) in 
BERUMPUN

International Journal of Social, Politics, and Humanities

https://berumpun.ubb.ac.id/index.php/BRP

the community. In addition, there are a number of functions and roles of education for the community, as expressed by Wuradji (Darwance et al., 2019) (1) The function of socialization, (2) The function of social control, (3) The function of preservation of community control; 4) The function of training and workforce development, (5) Selection and all functions of work, (6) The function of education and social change, (7) The function of cultural reproduction, (8) Cultural diffusion function, (9) The function of social education, (10) Social modification function. Material that is close to the reality of students' lives is the key to success in achieving the objectives of Social Science.

\section{LITERATURE REVIEW}

\subsection{Pela Gandong}

Pela Gandong is a social institution for people in Central Maluku, especially Seram Island, Ambon and Lease (Lokollo et al., 1997). Since time immemorial this social institution has lived and developed as an adhesive of social relations between one other countries and villages both Muslim villages and Christian villages (Sahusilawane, 2004). According to Uneputty, Pela is simply formulated as a brotherhood bond between two or more villages while Gandong is a brotherly relationship between two or more villages based on or based on the existence of genealogia relations between the villages concerned (Aponno, 2017). Where the ancestors from these villages came from the same descendants. After the Ambon conflict was over. To end the Ambon conflict which is very large in Indonesia's modern history. Pela Gandong becomes a medium for conflict resolution (Bakri, 2015). Thus, Pela Gandong became a model for peace education (Hasudungan et al., 2020).

\subsection{Peace Education}

This peace-building program in schools is expected to help reduce verbal experiences, physical torture, disorder, assault, destruction, fights, insults, and injuries. Furthermore, it can provide a feeling of mutual belonging among each other among students, increase social awareness, and build the ability of cooperation between students (Lestari, 2017). Peace education is a new step in harmonizing human life into the ideals of peace, peace education was initiated by the movement social as a result of the escalating social relations of human 
life due to differences in psychosocial views, ethics and emotions mixed with human interests themselves which lead to conflict (Gross, 2017). Research from Akbar et al (2018) however, the implementation of peace education has not been effective. Because, not all students can feel the value of peace in question. Because, true peace education is a difficult concept to understand. And in its implementation requires a comprehensive and holistic understanding that involves several aspects of education, especially the three main aspects namely, affective, cognitive and psychomotor.

Therefore, the application of peace education based on local wisdom is needed. As implemented by SMPN 9 Ambon City and SMPN 4 Salahutu Liang Central Maluku District. In the end, this research is to reveal and describe how the application of peace education based on local wisdom of Pela Gandong is integrated in Social Science.

As for the research that is considered relevant to this research, including research conducted by:

1. Relevant research that examines how peace education in Maluku is a dissertation titled Peace Education in the Moluccas, Indonesia: Between Global Models and Local Interests (Amirrachman, 2012). This dissertation examines the impact of peace education projects supported by foreign institutions on selected schools in the conflict-affected Maluku province of Indonesia. This study reveals that the orientation of a culture-exclusive peace education curriculum - which favors one group over another - will not help overcome the strengths and social inequalities rooted in Maluku society. However, optimistically, the leadership of principals from one particular school - who did not receive specific peace education interventions showed a significant influence in helping to bridge the relationship between students and to secure the support of parents and the community regardless of their religion and ethnic background. This dissertation analyzes that in conflict-affected societies where imbalances of power between religious and ethnic groups can still be found, and where competition for power and influence between them is still undermined by religious and ethnic sentiments - further exacerbated by traditional beliefs, which legitimizes religion. 
2. Arlen Florencia Hehakaya with the title of the Peace Education Program in Ambon, which is his thesis in the International Relations study program at Gadja Mada University (Hehakaya, 2012). This study aims to identify and analyze problems that hamper the optimal implementation of the peace education program in Ambon, as well as provide recommendations for the development of the program. Peace education program is basically a form of conflict prevention that is strived to instill the values of peace in young people through a peace education curriculum that is adapted to the conditions or needs of the region or the local State, which in this context is formally carried out in schools. Through this effort, the Maluku young generation in general, is expected to become a young generation who cultivates peace so that it can support sustainable peace.

Based on the researcher's explanation above, it is felt necessary to describe how integrated Social Science of peace education based on local wisdom Pela Gandong (case study of Ambon City SMPN 9 and SMPN 4 Salahutu Liang Central Maluku District).

\section{METHODOLOGY}

This study uses descriptive qualitative research methods with a plural case study approach. Case studies are empirical investigations that investigate contemporary phenomena in real life contexts, especially when the boundaries between the object of study and the context are unclear. This overcomes a technically different situation where there will be more interesting variables than the data points, and the results depend on a variety of sources of evidence, with data that needs to be included by means of triangulation, and as another result of the benefits of developing theoretical proposals to guide collection and data analysis (Ebneyamini \& Moghadam, 2018). Data collection was carried out by means of literature study, interviews, participatory observation, and document analysis.

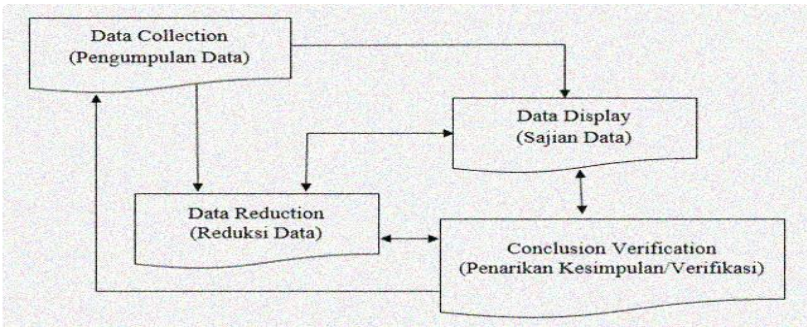

Figure 1.1 Interactive Analysis Model 
Sources: (M.B Miles and A.M.Huberman, 1992:20).

Interpretative analysis is generally seen as carried out in three stages: deconstruction, interpretation, and reconstruction. These stages occur after preparing data for analysis. Namely, after interview transcription or focus group and verification of transcript with recording.

Deconstruction refers to breaking down data into component parts to see what is included. It takes reading and rereading interviews or focus group transcripts and then splitting the data into categories or codes that describe the content. Interpretation follows deconstruction and refers to understanding and understanding the data encoded. This involves comparing data codes and categories within and across transcripts and across variables that are considered important for research. Reconstruction refers to re-creating or repackaging prominent codes and themes in a way that shows the relationships and insights gained in the interpretation phase and which explains them more broadly given existing knowledge and theoretical perspectives. Reconstruction requires contextualization of findings, namely positioning and framing it in existing theories, evidence, and practice.

\section{RESULTS AND DISCUSSION}

Fountain (1999) outlines the conception of the United Nations Children's Fund (UNICEF) about peace education which is a process of promoting knowledge, skills, attitudes and values about peace among students. According to Lederach (1997) for example, the greatest resources for maintaining peace in the long run are always rooted in the local population and their culture. Peace education can be disseminated to students using subjects in the school curriculum in Nigeria. Subjects, such as History, Social Science, Geography, Government and Religious Studies are relevant in this case. In History, students are made to understand past and present events in their community and use knowledge to improve their future. History will make students appreciate the factors that make national unity and global understanding (West Africa Examination Council, 1998).

Social Science will make students learn how to live in harmony in a society where many different groups live side by side. Students learn topics such as socialization, conflict, 
BERUMPUN

International Journal of Social, Politics, and Humanities

https://berumpun.ubb.ac.id/index.php/BRP

cooperation, heroes, heroes, ethical diversity, human rights and problems that arise in society. Social Science should instill in students disciplinary action, tolerance, and similar actions that will encourage the peaceful co-existence of people in society. All of the above are included in the objectives of peace education.

In Indonesia, the objective of local wisdom-based education is in accordance with Law No. 20 of 2003 concerning the National Education System Article 3, stating that national education serves to develop the capabilities and shape the dignified character and civilization of the nation in order to educate the public. national life. National education aims to develop the potential of students to become human beings who are loyal and serve God Almighty, have a noble character, healthy, knowledgeable, capable, creative, independent, and become democratic and responsible citizens.

While education-based benefits (b) reflect cultural values, (c) participate in shaping the nation's character, (d) contribute to the creation of national identity, and (e) take part in preserving the nation's culture. In addition, the model of cultural integration in learning can enrich local culture (ethnic) which in turn can also develop and strengthen national culture which is the culmination of local culture and developing ethnic cultures such as Pela Gandong. Culture-based learning can be integrated as a tool for the learning process to motivate students to apply knowledge, work cooperatively, and perceive relationships between various subjects.

In accordance with the statement above, the 2017 Social Science syllabus is the result of an improvement in the previous document Attachment to the Regulation of the Minister of Education and Culture of the Republic of Indonesia Number 58 Year 2014: (1) actually provides space for contextualization of learning according to environmental conditions and students. Contextual in Social Science is implemented so that learning is more interesting, concrete and in accordance with the experience of students. The teacher can take the topics that are in the surrounding environment, in the form of the school environment, rural communities, and urban communities both on a scale and local, national and global scale. Topics and problems that can be raised for example environmental damage, poverty, water scarcity, history of local heroism, social conflict, scarcity of goods, and so on. In discussing 
these topics the teacher can study from various perspectives of the social sciences and humanities, and apply Social Science concepts such as location, place characteristics, spatial interactions, resources, scarcity, social interactions, culture and technology. Social Science as a compulsory subject at the junior high level seems to be optimized to make local wisdom a source of learning (Suprapto \& Yudha, 2019). The contextualization of Social Science is directed at fostering environmental awareness, understanding the potential advantages of an area, getting to know local and national cultures, understanding problems from the point of view of weaknesses or limitations. Students become motivated and play an active role in solving problems, both through ideas, ideas and actions (behavior). Thus, students are expected to become heirs of a strong, responsible, creative, innovative, competitive, and cultured nation of Indonesia.

Material developed in learning should prioritize regional excellence and needs, in the form of location, economic, social, political, historical and cultural excellence. For example, Social Science that is integrated with peace education based on local wisdom of Pela Gandong. This was done considering the Ambon Maluku conflict in addition to causing hundreds of thousands of fatalities. It also breaks the harmony between religious communities, changes in personality between individuals and groups, the crippling wheel of the economy and the polarization among Ambonese Maluku people to date. Since 2013, SMPN 9 Ambon City and SMPN 4 Salahutu Liang have held brotherhood ties (Pela Gandong) in the world of education. As a symbol that there has been peace building in the field of education (Harmusial, 2019).

According to Kartadinata et al (2018) important elements in peace education consist of:

1. Attitude / Value

Self-esteem, respect for others, gender equality, respect for life / non-violence, compassion, global concerns, ecological concerns, cooperation, openness \& openness, justice, social responsibility, and positive vision.

2. Knowledge

Peace knowledge consists of:

- The concept of holistic peace 
- Causes of conflict \& violence

Some peaceful alternatives:

Ceasefire, non-violence-philosophy \& practice, resolution, transformation, conflict prevention, human rights, human solidarity, democratization, development based on justice and sustainable development.

3. Skills

Peace skills consist of, reflection, critical thinking \& analysis, decision making, imagination, communication, conflict resolution, empathy for group development.

Refer to the important elements in peace education above. Then, further facilitate the writer in finding the values of peace education in Pela Gandong. Following are the results of the writer's search for the values of Pela Gandong peace education, namely:

1. Concepts; the lives of Basudara (Brothers), Kidabela (one heart, one feeling and one family), Potong di kuku rasa di daging, Sitakaka walike (a brotherhood that lives in harmony and peace), Ale Rasa Beta Rasa (have empathy with others), Ain ne ain (belong to one another), Kalwedo (Legal evidence of ownership of Indigenous Peoples, joint ownership), Sagu Salempeng di pata dua (a life of caring and sharing), and so on are local content that is packaged in the tradition of harmonizing siblings in Maluku.

2. Pela Gandong have become social institutions that have developed as an glue of social relations between a Muslim village and a Christian village.

3. Pela Gandong are very functioning in regulating the system of social interaction of indigenous peoples that transcends various fields.

4. Pela Gandong as a model of friendship or system of brotherhood, or a system of fellowship that was developed between all indigenous people from two or more villages. The system ties have been established by the ancestors in special circumstances with certain rights and obligations agreed upon.

5. Pela Gandong made people participate in building churches, mosques, and other public facilities.

6. Pela Gandong has the collective concept of being brothers and sisters, and is related to the common ancestral heritage, having an important effect on the spirit of togetherness.

7. Pela Gandong is able to act as a cohesive instrument to help build the reconciliation process.

The implementation of Pela Gandong peace education values in Social Science at SMPN 9 Ambon City and SMPN 4 Salahutu Liang Central Maluku District greatly affected the 
formation of tolerance character, preparing students to be able to live in society and transfer knowledge about peace. Students who were previously excluded and polarized because of the Ambon conflict. Traumatized, the story of the Ambon conflict made a deep cut. There are many messages and advice from parents "do not eat this, do not go there, later there is like this". Communication that is built by parents with generations who do not experience conflict so as to make fear exist in students. So, students do not want to go anywhere that is inhabited by different religions. As a result, there is a partition or segregation. In addition, lately many hoaxes (hoax news) are circulating, news that want to frighten. In fact, when experienced firsthand is not as imagined in the news, far different from reality.

Table 1.1

Students based on Religion

\begin{tabular}{cccc}
\hline School name & $\begin{array}{c}\text { Number } \\
\text { of } \\
\text { Students }\end{array}$ & \multicolumn{2}{c}{$\begin{array}{c}\text { Students based } \\
\text { on Religion }\end{array}$} \\
\cline { 3 - 4 } & & $\begin{array}{c}\text { Islam } \\
\text { (in\%) }\end{array}$ & $\begin{array}{c}\text { Christian } \\
\text { (in\%) }\end{array}$ \\
\hline $\begin{array}{c}\text { SMP Negeri 9 Ambon } \\
\text { City }\end{array}$ & $\begin{array}{c}1431 \\
\text { Students }\end{array}$ & $1 \%$ & $99 \%$ \\
\hline $\begin{array}{c}\text { SMP Negeri 4 Salahatu } \\
\text { Liang Central Maluku }\end{array}$ & $\begin{array}{c}414 \\
\text { Students }\end{array}$ & $100 \%$ & $0 \%$ \\
\hline
\end{tabular}

Source: (Kementerian Pendidikan dan Kebudayaan Republik Indonesia, 2019) and (Author's Process)

Questioning about following the development discourse on peace education after conflict in relation to Social Science is found in Basic Competence (KD). 3.2 class VIII. Namely, analyzing the influence of social interaction in different spaces on socio-cultural life and the development of national life. In the Ilmu Pengetahuan Sosial syllabus, detailing the main materials in K.D 3.2 is as follows:

1. The effect of social interaction (social mobility) on social and cultural life Plurality (religion, culture, ethnicity, work) of Indonesian people.

2. Conflict and integration.

According to Henny Liklitiwatil, Teacher of SMPN 9 Ambon City revealed that the implementation of the Pela Gandong-based peace education value on Social Science had an impact. The following statement:

The impact of the formation of the character of tolerance, preparing students to be able to live in the midst of society and form knowledge about peace. Students who were previously excluded and polarized because of the Ambon conflict. Communication built 
by parents with generations who do not experience conflict (their children) lacks the values of peace education. So that makes fear there.

Regarding teachers' perceptions of integrated Social Science in peace education based on local wisdom Pela Gandong. The following is an explanation from a teacher from SMPN 4 Salahutu Liang, Muhammad Yusuf:

Social Science, we need to learn from history. Because, by studying history, don't occasionally forget history. Therefore, it is a slogan developed by Soekarno himself, JAS MERAH. If there are historical content in Social Science from class VII to class IX. My hope for the future. That, the intensity of the curriculum is sharpened in understanding history. Because, with history students understand especially the history of conflict, students must learn. With the history of conflict, we can know, from tomorrow we can be careful. Because, conflicts are ridden, many are ridden with irresponsible parties, students need to learn history.

A student from SMPN 9 Ambon City named Yohannes Pattikawa expressed his understanding of Social Science that included peace education materials based on Pela Gandong's local wisdom as follows:

Social Science subjects have material on conflict. From there I understood the meaning of conflict and its causes. Conflicts are like riots, like the Ambon conflict. Conflict can make us alienated and it's not good. Better a peaceful life. A peaceful life is a peaceful, safe and peaceful life. Coexist and treat friends as our own siblings. No fighting, no offense to friends, no revenge on friends. In Social Science, there are teachers giving lessons about peace education. Teacher, we convey peace we must do. Because, peace makes us feel close to each other. So, peace education is in Social Science and most importantly. Because peace is truly loved by everyone. The teacher has given motivation. The teacher says: "Learn first, be enthusiastic, be brave and be responsible". The teacher says "we as students, we must have experience of peace. Like living as siblings and siblings like siblings.

Meanwhile, according to a student from SMPN 4 Salahutu Liang named Aira Fajira Tuny, the author asked for her opinion on Social Science that included peace education materials based on local wisdom in Pela Gandong. Give the following statement:

That there is an impact of peace education in Social Science. Like doing; talking with fellow friends with kind words. Not fighting with one friend with another friend, talking with courtesy. Living together must carry out life well. We, the majority of Muslims and Christians must work together to build something good, no one can intend evil. Such as SMPN 4 Liang and SMPN 9 Ambon City which have become Pela Gandong (brotherhood). 
BERUMPUN

International Journal of Social, Politics, and Humanities

https://berumpun.ubb.ac.id/index.php/BRP

Explanation from teachers and students both SMP 9 Ambon City and SMP 4 Salahutu Liang Central Maluku District can be concluded that: local wisdom Pela Gandong-based peace education in learning Social Science successfully implemented and achieved its objectives. Social Science will make students learn how to live in harmony in a society where many different groups live side by side. Especially for areas that have just experienced conflict and are just starting the process of healing and maintaining peace that is painstakingly obtained. Students learn topics such as socialization, conflict, cooperation, heroes, diversity, ethics, human rights and social problems that exist in society. Social Science should instill in students the actions of discipline, tolerance, and such actions that will encourage the peaceful co-existence of people in society. All of the above are included in the objectives of peace education.

\section{CONCLUSION}

Social Science integrated peace education not only teaches cognitive but also social skills and shapes attitudes. This becomes important to manage the diversity that exists in Indonesia so as to avoid conflicts like Ambon in 1999-2003. When learning that includes peace education on Social Science takes place and achieves what has been intended. So, peace in Ambon, Maluku will continue to be maintained. Local, contextual, and relevant material to students makes it easier for teachers to achieve learning goals. The implementation of Pela Gandong peace education values in Social Science at SMPN 9 Ambon City and SMPN 4 Salahutu Liang greatly affected the formation of tolerance character, preparing students to be able to live in harmony in society. And reduce the trauma and mutual suspicion of students between the two schools. Pela Gandong-based peace education in Social Science at SMPN 9 Ambon City and SMPN 4 Salahutu Liang Central Maluku has become a pilot for other schools in Maluku Province to immediately address the segregation that still exists through Social Science.

\section{ACKNOWLEDGEMENT}

The author said to all parties who had supported in this research process.

\section{ABOUT THE AUTHOR}

The author is a graduate of the Master of History Education at Sebelas Maret University in 2020. And currently teaches history subjects at SMAN 1 Rupat, Riau Province. 


\section{REFERENCES}

[1] Adam, J. (2013). A Comparative Analysis on the Micro-level Genealogies of Conflict in the Philippines' Mindanao Island and Indonesia's Ambon Island. Oxford Development Studies, 41(2), 155-172. https://doi.org/10.1080/13600818.2013.789841

[2] Akbar, M. S., Rukman, Z. H., Sabila, A., \& Anggraeni, L. (2018). Persepsi Siswa Tentang Pendidikan Perdamaian Dalam Membangun Interaksi Sosial Yang Positif. Sosietas, 8(1), 434-437. https://doi.org/10.17509/sosietas.v8i1.12495

[3] Amirrachman, A. (2012). Peace education in the Moluccas, Indonesia: between global models and local interests [Universiteit van Amsterdam]. https://dare.uva.nl/document/2/145859

[4] Aponno, E. H. (2017). Budaya Lokal Maluku "Pela Gandong" Dalam Konteks Perilaku Organisasi. Jurnal Manajemen STIE Muhammadiyah Palopo, 3(1), 12-25. https://doi.org/10.35906/jm001.v3i1.200

[5] Bakri, H. (2015). Resolusi Konflik melalui Pendekatan Kearifan Lokal Pela Gandong di Kota Ambon. The POLITICS : Jurnal Magister Ilmu Politik Universitas Hasanuddin, 1(1), 51-60. http://journal.unhas.ac.id/index.php/politics/article/view/133/pdf

[6] Baldo, M., \& Furniss, E. (1998). Integrating life skills into the primary curriculum.

[7] Darwance, D., Haryadi, D., Fahria, I., Samudra, A., Ramadhanty, D., \& Erika, E. (2019). Cultural Based Tourism Development in Pasir Putih Village Tukak Sadai District, Bangka Selatan District Through Agik Barik Festival. Berumpun: International Journal of Social, Politics, and Humanities, 2(2), 93-105. https://doi.org/10.33019/berumpun.v2i2.22

[8] Ebneyamini, S., \& Moghadam, M. R. S. (2018). Toward Developing a Framework for Conducting Case Study Research. International Journal of Qualitative Methods, 17(1), 111. https://doi.org/10.1177/1609406918817954

[9] Fountain, S. (1999). Peace Education Peace Education In UNICEF. In United Nations Children's Fund. United Nations Children's Fund Programme Publications. https://doi.org/10.1023/A:1019128224779

[10] Gross, Z. (2017). Revisiting peace education: Bridging theory and practice International and comparative perspectives - Introduction. Research in Comparative and International Education, 12(1), 3-8. https://doi.org/10.1177/1745499917698290

[11] Habib Shulton Asnawi dan Eka Prasetiawati. (2018). Pribumisasi Islam Nusantara dan Relevansinya dengan Nilai-Nilai Kearifan Lokal di Indonesia. Jurnal Fikri : Jurnal Kajian Agama, Sosial Dan Budaya, 3(1), 368.

[12] Hartanti, Nur Lailiya, Fathul Karimul Khair, Z. A. (2018). PELA GANDONG: SARA CONFLICT RESOLUTION METHOD BASE ON LOCAL WISDOM IN MOLLUCAS. 336-342.

[13] Hasudungan, A. N., Sariyatun, S., \& Joebagio, H. (2020). Pengarusutamaan Pendidikan Perdamaian Berbasis Kearifan Lokal Pela Gandong Pasca Rekonsiliasi Konflik Ambon di Sekolah. Jurnal Lektur Keagamaan, 17(2), 409. https://doi.org/10.31291/jlk.v17i2.664

[14] Hehakaya, A. F. (2012). PROGRAM PENDIDIKAN DAMAI DI AMBON [Universitas Gadja Mada]. https://repository.ugm.ac.id/100399/

[15] International Crisis Group. (2000). INDONESIA'S MALUKU CRISIS: THE ISSUES. https://www.crisisgroup.org/asia/south-east-asia/indonesia/indonesias-malukucrisis-issues\#

[16] Kementerian Pendidikan dan Kebudayaan Republik Indonesia. (2013). Materi Pelatihan 
Guru Implementasi Kurikulum 2013, SMA/MA dan SMK/MAK, Sejarah Indonesia.

[17] Kementerian Pendidikan dan Kebudayaan Republik Indonesia. (2019). Temukan Informasi Sekolah di seluruh Indonesia. Sekolah.Data.Kemdikbud.Go.Id/.

[18] Lederach, J. P. (1997). Building Peace: Sustainable Reconciliation in Divided Societies. Library of British Council.

[19] Lestari, M. (2017). Restrukturisasi Pendidikan Awal Perdamaian di Sekolah. Seminar Bimbingan Dan Konseling, 1(1), 267-279. http://pasca.um.ac.id/conferences/index.php/snbk/article/view/228

[20] Lokollo, J. E., Pattiruhu, C. M., Lestaluhu, M., Timisela, I., Limahelu, D., Limahelu, L., Leatemia, J., \& G, L. (1997). Seri Budaya Pela Gandong dari Pulau Ambon. Lembaga Kebudayaan daerah Maluku.

[21] M.B Miles and A.M.Huberman. (1992). Analisa Data Kualitatif: (Penerjemah Tjetjep Rohendi $R$ ). Universitas Indonesia Press.

[22] Qurtuby, S. Al. (2013). Peacebuilding in Indonesia: Christian-Muslim Alliances in Ambon Island. Islam and Christian-Muslim Relations, 24(3), 349-367. https://doi.org/10.1080/09596410.2013.785091

[23] Sahusilawane, F. (2004). Sejarah Lahirnya Pela dan Gandong Antar Negeri-negeri Di Pulau Ambon. Laporan Penelitian Sejarah dan Nilai Tradisional Ambon. https://www.pustaka-bpnbkalbar.org/pustaka/laporan-penelitian-sejarah-dan-nilaitradisional-ambon- 0

[24] Sunaryo Kartadinata \& Riswanda Setiadi \& Ilfiandra. (2018). Pedagogi Pendidikan Perdamaian Rujukan Pengembangan Sekolah Aman dan Damai. Universitas Pendidikan Indonesia Press.

[25] Suprapto, W., \& Yudha, N. K. (2019). PURUN: MERAJUT EKOLOGI DAN TRADISI DI KOTA TIKAR DALAM KONTEKS IPS. Jurnal Pendidikan Ilmu Pengetahuan Sosial Indonesia, 4(September),

47-54. https://journal.stkipsingkawang.ac.id/index.php/JurnalPIPSI/article/download/1286 /pdf_2

[26] Turner, K. T. (2006). Competing Myths of Nationalist Identity: Ideological Perceptions of Conflict in Ambon , Indonesia [Murdoch University]. https://researchrepository.murdoch.edu.au/id/eprint/374/

[27] Wenno, I. ., \& Akihary, W. (2010). Kebutuhan Model Budaya Pela Gandong Berbasis Pembangunan Di Provinsi Maluku. LiNGUA: Jurnal Ilmu Bahasa Dan Sastra, 5(2). https://doi.org/10.18860/ling.v5i2.626

[28] West Africa Examination Council. (1998). WAEC regulations and syllabuses for the West Africa Senior Secondary School Certificate Examination (WASSCE) 1998-2000.

\section{Interview}

Fajira Tuny, Aira. Central Maluku, November 8, 2019.

Harmusial, Lely Diaz. 2018. Ambon, January 29, 2018.

Liklitiwatil, Henny. 2019. Ambon, November 13, 2019. 


\section{BERUMPUIN}

International Journal of Social, Politics, and Humanities

https://berumpun.ubb.ac.id/index.php/BRP
P-ISSN: 2622-8831

E-ISSN: $2622-8335$
Vol. 3 No. 2 October 2020

Pattikawa, Yohannes. 2019. Ambon, November 13, 2019.

Yusuf, Muhammad. 2019. Central Maluku, November 8, 2019. 